CLINICAL STUDY

\title{
Parallel downregulation of retinol-binding protein-4 and adiponectin expression in subcutaneous adipose tissue of non-morbidly obese subjects
}

\author{
Montserrat Broch ${ }^{1,2}$, Maria Teresa Auguet ${ }^{1,2,3}$, Rafael Ramírez ${ }^{3}$, Montserrat Olona ${ }^{4}$, Carmen Aguilar ${ }^{1,2}$, \\ Ana Megia ${ }^{2,5,9}$, Maria José Alcaide ${ }^{6}$, Rosa Pastor ${ }^{7}$, Salomé Martínez ${ }^{8}$, Enric Caubet ${ }^{10}$, Antonio Garcia-España ${ }^{11}$ \\ and Cristóbal Richart ${ }^{1,2,3}$ \\ ${ }^{1}$ CIBER (CBO6/03) Fisiopatologia de la Obesidad y Nutrición, Instituto de Salud Carlos III, Avda Monforte de Lemos, Madrid, Spain, ${ }^{2}$ Department of \\ Medicine and Surgery, Universitat Rovira i Virgili. Sant Llorenç 21, 43201 Reus, Tarragona, Spain, ${ }^{3}$ Internal Medicine Service, ${ }^{4}$ Epidemiology and \\ Statistic Unit, ${ }^{5}$ Diabetes and Endocrinology Service, ${ }^{6}$ Surgery Service, ${ }^{7}$ Hormonal Laboratory and ${ }^{8}$ Pathology Service, Hospital Universitari de Tarragona \\ Joan XXIII, Dr Mallafré Guasch s/n 43007, Tarragona, Spain, ${ }^{9}$ CIBER (CBO7/08) Diabetes, Instituto de Salud Carlos III, Avda Monforte de Lemos, \\ Madrid, Spain, ${ }^{10}$ Surgery Service, Hospital de Sant Pau i Santa Tecla, Rambla Vella, 14, 43003, Tarragona, Spain and ${ }^{11}$ Institut d'Investigació Sanitaria \\ Pere Virgili, Sant Llorenç 21, 43201 Reus, Tarragona, Spain \\ (Correspondence should be addressed to M Broch; Email: mbroch.hj23.ics@gencat.cat)
}

\begin{abstract}
Context and objective: Adipokines are involved in the etiopathology of obesity-related disorders. Since the role of adipokine retinol-binding protein-4 (RBP4) in obesity remains uncertain and its relationship with other adipokines and inflammatory markers has not been examined in detail, we investigated the relationships of RBP4 mRNA expression and circulating protein levels with obesity, anthropometric and metabolic variables, as well as with obesity-related inflammatory markers adiponectin and C-reactive protein.

Subjects and methods: One-hundred and twenty-five subjects participated, 36 lean (body mass index (BMI): $<25 \mathrm{~kg} / \mathrm{m}^{2}$ ) and 89 obese (overweight/obese; BMI: $\geq 25<40$ ) whose anthropometric and metabolic variables were assessed. mRNA expression was quantified by real-time PCR in subcutaneous adipose tissue (s.c.-AT) of 46 subjects.

Results: There was a tendency for circulating RBP4 levels to positively correlate with waist circumference $\left(\beta=0.29, P=0.08 ; R^{2}=0.08\right)$, but there was no significant association with the obesity-related parameters analysed. RBP4 and adiponectin mRNA expression levels were similarly downregulated in the s.c.-AT of obese subjects (0.5-fold); however, RBP4 downregulation did not affect its circulating protein levels. The expression of RBP4 and adiponectin was positively correlated even after controlling for confounding factors $\left(\beta=0.59, P<0.0001 ; R^{2}=0.40\right)$.

Conclusions: In our population, RBP4 circulating levels were not significantly correlated with obesityrelated parameters, although a tendency to correlate with waist circumference suggests a relationship with insulin resistance and other metabolic disorders. In addition, our results suggest that the production of RBP4 by other tissues such as liver, rather than s.c.-AT, may be involved in regulating RBP4 circulating levels.
\end{abstract}

European Journal of Endocrinology $16187-94$

\section{Introduction}

In addition to its main metabolic role of storing energy in the form of fat, adipose tissue (AT) is now considered an active endocrine organ that secretes a variety of bioactive peptides. These peptides are known as 'adipokines' and they coordinate biological processes such as energy metabolism, immune and neuroendocrine functions (1-3).

Obesity is a condition that is associated with low-level chronic inflammation, insulin resistance (IR), hyperlipidaemia and other metabolic disorders (4). There is now growing evidence that adipokines are important in the etiopathology of obesity-related disorders, either through a traditional (circulating) hormonal effect or by a local action in the AT (5).

Since the circulating levels of a recently identified adipokine that acts as a carrier of retinol (vitamin A) in the blood, retinol-binding protein-4 (RBP4), have been positively correlated with obesity and IR in an adipocyte-specific glucose transporter 4 knock-out mouse (Glut $4^{-1-}$ ) model (6), and, in this model, an insulin-sensitising drug reduced the elevated levels of RBP4 transcripts in AT as well as its systemic levels (6), it has been proposed that RBP4 may be behind the adipocyte-muscle connection that links obesity and IR 
(6). However, its role in human obesity and IR physiopathology is still unclear (7-14).

In the present study, and, as an extension of our recent analysis of circulating RBP4 levels in 107 nondiabetic men with a variable degree of obesity (11), we have assessed circulating RBP4 levels and RBP4 expression in subcutaneous adipose tissue (s.c.-AT) in lean and obese patients. In order to gain a more complete understanding of how RBP4 may influence human obesity, we also assessed the levels of adiponectin and C-reactive protein (CRP), which are related to adiposity and its metabolic disorders and are differentially expressed in human AT. Indeed, while the circulating levels of CRP, an established inflammatory marker, are positively associated with obesity and IR (15), the circulating levels of adiponectin are inversely correlated with IR, obesity and CRP levels (16-19).

In order to clarify the role of RBP4 in human obesity, we have studied, in obese and non-obese subjects without diabetes, the relationship between circulating RBP4 levels and s.c.-AT RBP4 mRNA expression with adiposity parameters, IR indices and lipid parameters. In addition, to integrate the role of RBP4 with that of other obesity-associated molecules, we examined the relationship between s.c.-AT mRNA expression and circulating levels of RBP4, adiponectin and CRP. We also assessed RBP4, adiponectin and CRP expressions in s.c.-AT fractions: mature adipocytes and non-fat cells of the stromal-vascular fraction (SVF).

\section{Subjects and methods}

\section{Study population}

Serum levels of RBP4 were measured in 125 subjects: 36 lean subjects, mean age $50.8 \pm 16.4$ years $(25$ men and 11 women) with a body mass index (BMI): $<25 \mathrm{~kg} / \mathrm{m}^{2}$; and 89 obese subjects mean age 57.8 \pm 14.3 years (58 men and 31 women) with a BMI between 25 and $39.9 \mathrm{~kg} / \mathrm{m}^{2}$. Forty-six subjects participated in the AT expression study: 22 lean subjects, mean age $46.9 \pm 16.3$ years (12 men and 10 women); and 24 obese, mean age $54.63 \pm 14.2$ years (13 men and 11 women). Subjects were recruited at the endocrinology service of the University Hospital Joan XXIII and the Sant Pau i Santa Tecla Hospital (Tarragona, Spain). All subjects were of Caucasian origin and their body weight had fluctuated by no more than $2 \%$ for at least three months before the study. They showed no evidence of any metabolic disease other than obesity. Hypolipemiants in all subjects and hormone therapy in menopausal women were discontinued 4 weeks before the study. Liver and renal diseases were specifically excluded through a biochemical work-up. Inclusion criteria were BMI $<40 \mathrm{~kg} / \mathrm{m}^{2}$, absence of any systemic disease and absence of clinical symptoms and signs of infection during the previous month. This was ascertained using a structured questionnaire answered by the patient. Patients' additional clinical data are given in Tables 1 and 2. Although our obese population consisted of slightly obese (overweight; (BMI: $25<30$ ) and moderately obese subjects (BMI: $30<40)$ ), for simplicity reasons we will refer to them as the obese population' throughout the manuscript.

\section{Anthropometrical measurements and analytical methods}

Body height and weight were measured with the patient standing in light clothes and without shoes. BMI was calculated as body weight divided by height squared $\left(\mathrm{kg} / \mathrm{m}^{2}\right)$. The subjects' waist was measured with a soft tape midway between the lowest rib and the iliac crest. Blood pressure was measured in the supine position on the right arm after 10 min of rest, and values used in the analysis are the average of three readings taken at 5 min intervals. The same physician performed all examinations. Plasma and serum samples were stored at $-80{ }^{\circ} \mathrm{C}$ until analytical measurements were taken, except for glucose, which was determined immediately after blood was drawn. The serum glucose and lipid profile parameters were determined using standard clinical biochemistry methods. The level of low-density lipoprotein (LDL)-cholesterol was estimated using the formula: total cholesterol-high-density lipoprotein (HDL)-cholesterol-(triglyceride $\div 5$ ). Fasting insulin was measured in duplicate using a monoclonal IRMA (Medgenix Diagnostics, Fleunes, Belgium), with a sensitivity of $4.1 \mu \mathrm{U} / \mathrm{l}$. The degree of IR was measured using homeostasis model assessments of IR index (HOMA-IRI) with the equation HOMA-IRI=insulin

Table 1 Metabolic characteristics of lean and obese subjects.

\begin{tabular}{|c|c|c|c|}
\hline & $\begin{array}{l}\text { Lean BMI } \\
<25(n=36)\end{array}$ & $\begin{array}{c}\text { Obese BMI } \\
\geq 25<40 \\
(n=89)\end{array}$ & $\boldsymbol{P}$ \\
\hline Age (years) & $50.8 \pm 16.4$ & $57.8 \pm 14.3$ & $0.01^{*}$ \\
\hline Sex ( $n, \mathrm{men} /$ women $)$ & $25 / 11$ & $58 / 31$ & 0.65 \\
\hline BMI $\left(\mathrm{kg} / \mathrm{m}^{2}\right)$ & $22.8 \pm 1.8$ & $29.5 \pm 3.5$ & $<0.0001^{*}$ \\
\hline Waist (cm) & $82.4 \pm 9.6$ & $99.9 \pm 11.4$ & $<0.0001^{*}$ \\
\hline Fasting glucose (mM) & $5.1 \pm 0.7$ & $5.5 \pm 0.6$ & $<0.0001^{*}$ \\
\hline Fasting insulin $(\mu \mathrm{U} / \mathrm{l})$ & $4.4 \pm 3.9$ & $5.8 \pm 3.8$ & $0.02^{*}$ \\
\hline HOMA $(\mu \mathrm{U} / \mathrm{ml} \times \mathrm{mM})$ & $0.8+0.06$ & $1.5+1.2$ & $<0.0001^{*}$ \\
\hline QUICKI & $0.4 \pm 0.04$ & $0.3 \pm 0.05$ & $<0.0001^{*}$ \\
\hline $\mathrm{SBP}(\mathrm{mmHg})$ & $122.4 \pm 17.2$ & $132.9 \pm 22.0$ & $0.004^{*}$ \\
\hline $\mathrm{DBP}(\mathrm{mmHg})$ & $70.9 \pm 10.9$ & $76.3 \pm 10.1$ & $0.003^{*}$ \\
\hline Total cholesterol (mM) & $4.9 \pm 1.0$ & $5.5 \pm 0.8$ & $0.009^{*}$ \\
\hline Triglycerides (mM) & $1.1 \pm 0.6$ & $1.5 \pm 0.7$ & $0.03^{*}$ \\
\hline LDL cholesterol (mM) & $3.2 \pm 0.9$ & $3.9 \pm 0.7$ & $0.009^{*}$ \\
\hline HDL cholesterol (mM) & $1.4+0.2$ & $1.2+0.1$ & $<0.0001^{*}$ \\
\hline RBP4 $(\mu \mathrm{g} / \mathrm{ml})$ & $30.2 \pm 1.0$ & $30.4 \pm 3.4$ & 0.47 \\
\hline Adiponectin $(\mu \mathrm{g} / \mathrm{ml})$ & $15.4 \pm 5.8$ & $11.5 \pm 5.0$ & $0.001^{*}$ \\
\hline $\mathrm{CRP}(\mathrm{mg} / \mathrm{dl})$ & $1.3 \pm 1.3$ & $3.0 \pm 3.8$ & $0.002^{*}$ \\
\hline
\end{tabular}

Data are mean +S.D.; BMI, body mass index; SBP, systolic blood pressure; DBP, diastolic blood pressure; LDL, low-density lipoprotein; HDL, high-density lipoprotein. Differences between groups were analysed by two-tailed Student's $t$-test. *Denotes statistical differences between the groups $(P<0.05)$. 
Table 2 Metabolic characteristics of lean and obese subjects for the expression study.

\begin{tabular}{lccc}
\hline & $\begin{array}{c}\text { Lean BMI } \\
<\mathbf{2 5}(n=22)\end{array}$ & $\begin{array}{c}\text { Obese BMI } \\
\geq \mathbf{2 5}<\mathbf{4 0} \\
(n=24)\end{array}$ & $\boldsymbol{P}$ \\
\hline Age (years) & $47.0 \pm 16.3$ & $55.0 \pm 14.2$ & 0.11 \\
Sex $(n, \mathrm{men} /$ women) & $12 / 10$ & $13 / 11$ & 0.76 \\
BMI $\left(\mathrm{kg} / \mathrm{m}^{2}\right)$ & $23.0 \pm 1.4$ & $30.0 \pm 3.9$ & $<0.0001^{*}$ \\
Waist $(\mathrm{cm})$ & $81.1 \pm 9.2$ & $100.3 \pm 9.9$ & $<0.0001^{*}$ \\
Fasting glucose $(\mathrm{mM})$ & $5.1 \pm 0.4$ & $5.7 \pm 0.9$ & 0.05 \\
Fasting insulin $(\mu \mathrm{U} / \mathrm{l})$ & $3.3 \pm 2.6$ & $5.5 \pm 2.8$ & $0.04^{*}$ \\
HOMA $(\mu \mathrm{U} / \mathrm{ml} \times \mathrm{mM})$ & $0.7 \pm 0.4$ & $1.4 \pm 0.7$ & $0.03^{*}$ \\
QUICKI & $0.4 \pm 0.04$ & $0.3 \pm 0.05$ & $0.03^{*}$ \\
SBP (mmHg) & $126.3 \pm 15.9$ & $133.1 \pm 15.6$ & 0.27 \\
DBP (mmHg) & $72.9 \pm 10.2$ & $81.9 \pm 7.8$ & $0.007^{*}$ \\
Total cholesterol $(\mathrm{mM})$ & $4.6 \pm 0.1$ & $5.7 \pm 1.0$ & $0.02^{*}$ \\
Triglycerides $(\mathrm{mM})$ & $1.3 \pm 0.8$ & $1.6 \pm 1.3$ & 0.05 \\
LDL cholesterol $(\mathrm{mM})$ & $3.1 \pm 0.6$ & $4.1 \pm 1.0$ & $0.04^{*}$ \\
HDL cholesterol $(\mathrm{mM})$ & $1.3 \pm 0.3$ & $1.2 \pm 0.2$ & 0.53 \\
\hline
\end{tabular}

Data are mean \pm s.D.; BMI, body mass index; SBP, systolic blood pressure; DBP, diastolic blood pressure; LDL, low-density lipoprotein; HDL, highdensity lipoprotein. Differences between groups were analysed by MannWhitney $U$-test. *Denotes statistical differences between the groups $(P<0.05)$.

$(\mu \mathrm{U} / \mathrm{ml}) \times$ glucose $(\mathrm{mmol} / \mathrm{l}) / 22.5$ and with a quantitative insulin sensitivity check index (QUICKI) calculated as $1 /(\log$ insulin $(\mathrm{mU} / \mathrm{l})+\log$ glucose $(\mathrm{mg} / \mathrm{dl}))$. RBP4 in serum samples was measured by nephelometry (Dade Behring Inc., Marburg, Germany). The sensitivity of the method was $0.1 \mathrm{ng} / \mathrm{dl}$. CRP levels were determined by nephelometry with the high sensitivity CRP kit (Dade Behring Inc.) Sensitivity was $0.17 \mathrm{mg} / \mathrm{l}$. Plasma adiponectin was measured using the human adiponectin RIA kit (Linco Research, St Charles, MO, USA) with a detection limit of $1 \mathrm{ng} / \mathrm{ml}$. All samples were measured in duplicate.

\section{Blood and AT samples}

Blood samples were obtained from the subjects after an overnight fast. For the expression study, samples were obtained on the same day from the patients with abdominal elective surgical procedures (abdominal hernia surgery and cholecystectomy). Blood samples were collected before the surgical procedure. AT samples were obtained from the subcutaneous abdominal region (periumbilical region) and were immediately frozen in liquid nitrogen. Each hospital's ethics committee approved the study and informed consent was obtained from each subject.

\section{Isolation of adipocytes and stromal-vascular cells}

Subcutaneous AT samples from eight subjects, four men and five women (age: $52.5 \pm 13.4$ years and BMI: $28 \pm 1.6 \mathrm{~kg} / \mathrm{m}^{2}$ ) were immediately transported to the laboratory in M199 media (Gibco, Invitrogen Corporation), supplemented with $4 \%$ BSA and $5.5 \mathrm{mM}$ D-glucose and digested with $0.15 \mathrm{mg} / \mathrm{g}$ AT of collagenase type I (Sigma Inc.) for $1 \mathrm{~h}$ at $37^{\circ} \mathrm{C}$. Adipose cells were separated from undigested material (AT matrix) by filtration through $200 \mu \mathrm{m}$ mesh fabric. Mature adipocytes were separated from non-fat cells (SVF) by centrifugation for $10 \mathrm{~min}$ at $1500 \mathrm{~g}$. Isolated adipocytes and SVF cells were washed twice in $1 \times$ PBS for $5 \mathrm{~min}$ and stored at $-80{ }^{\circ} \mathrm{C}$.

\section{RNA analysis}

Selection of primers Primer sets were generated using genomic sequences obtained from Genbank of the National Centre for Biotechnology Information (NCBI) and the Primer3 (v.0.4.0) software. Primers were checked for potential homology to sequences other than the designated target in BLAST (NCBI) searches. The primers, expected cDNA length and annealing temperatures are provided in Table 3.

Verification of primer specificity To verify primer specificity, each primer set was used in a standard PCR to amplify cDNA generated by RT-PCR (Promega Corporation) using random hexamer priming of the total RNA isolated from normal s.c.-AT. Thermal cycling profile consisted of a pre-incubation step at $95^{\circ} \mathrm{C}$ for $10 \mathrm{~min}$, followed by 35 cycles of denaturation $\left(95^{\circ} \mathrm{C}\right.$, $1 \mathrm{~min})$, annealing $\left(55-66^{\circ} \mathrm{C}, 1 \mathrm{~min}\right)$ and extension $\left(72^{\circ} \mathrm{C}, 1 \mathrm{~min}\right)$. Products were run on an agarose gel and stained with ethidium bromide to confirm that only one band was amplified and that no primers dimers had formed. An aliquot of the PCR products was then purified using the QIAquick PCR purification kit (Qiagen Science) and sequenced to confirm target specificity. Aliquots of purified PCR products were used to construct standard curves for real-time PCR (see below).

RNA extraction and quantification Total RNA was extracted from frozen s.c.-AT samples and adipocyte fractions using RNeasy lipid tissue midi kit and from SVFs using RNeasy mini kit, (Qiagen Science, both).

Table 3 Primers sequences, cDNA length and annealing temperatures used for expression assessment of retinol-binding protein-4, adiponectin, C-reactive protein and housekeeping gene ( $\beta$-actin) by real-time PCR.

\begin{tabular}{|c|c|c|c|}
\hline Gene & $\begin{array}{l}\text { Sequence } \\
\text { sense } \\
\text { antisense }\end{array}$ & $\begin{array}{l}\text { cDNA } \\
\text { length } \\
\text { (bp) }\end{array}$ & $\begin{array}{c}\text { Annealing } \\
\text { temperature } \\
\left({ }^{\circ} \mathrm{C}\right)\end{array}$ \\
\hline $\begin{array}{l}\text { RBP4 } \\
\text { RBP4 }\end{array}$ & $\begin{array}{l}\text { gcctctttctgcaggacaac } \\
\text { gaaggtgcccaccatgtct }\end{array}$ & 132 & 60.7 \\
\hline $\begin{array}{l}\text { Adiponectin } \\
\text { Adiponectin }\end{array}$ & $\begin{array}{l}\text { gctgggagctgttctactgc } \\
\text { cgatgtctcccttaggacca }\end{array}$ & 233 & 55.8 \\
\hline $\begin{array}{l}\text { CRP } \\
\text { CRP }\end{array}$ & $\begin{array}{l}\text { gggacttctagcccctgaac } \\
\text { tgtctcttggtggcatacga }\end{array}$ & 321 & 55 \\
\hline $\begin{array}{l}\beta \text {-actin } \\
\beta \text {-actin }\end{array}$ & $\begin{array}{l}\text { ggacttcgagcaagagatgg } \\
\text { agcactgtgttggcgtacag }\end{array}$ & 234 & 66 \\
\hline
\end{tabular}


We verified RNA quality with a gel electrophoresis and optical density measurements. RT was performed with $1 \mu \mathrm{g}$ of total RNA using random hexamers (Promega Corporation). Real-time quantitative PCR for RBP4, adiponectin and CRP was performed using LightCycler Technology with a LightCycler FastStart DNA master SYBR green I kit (Roche Diagnostics), following the indications of the manufacturers' manual. To prepare the standard curves, purified PCR products encoding RBP4, adiponectin, CRP and $\beta$-actin (housekeeping gene) were cloned independently in the pCRII-TOPO (TOPO TA cloning kit; Invitrogen Corporation), digested with a restriction enzyme and checked by sequentiation. Standard curves and samples were run in duplicate in each real-time PCR. mRNA expression values were calculated from the standard curve by LightCycler quantification software using the crossing point value and the second derivative maximum method. Gene expressions were expressed relative to the expression of the $\beta$-actin housekeeping gene (ratio=mRNA gene/ mRNA housekeeping gene). All four PCRs showed PCR efficiencies close to 2.0. To avoid detection of non-specific PCR products, the purity of each amplified product was confirmed using a melting curve analysis.

\section{Statistical analysis}

The statistical analysis was performed with the SPSS/PC+statistical package (v.12 for Windows; Chicago, IL, USA). We previously calculated the sample size necessary to obtain a statistical power of $90 \%$. Assuming a circulating RBP4 value of $30 \pm 1.0 \mu \mathrm{g} / \mathrm{ml}$ in lean subjects, we need 21 obese patients to obtain a difference of five points with a risk $\alpha=0.05$. In the study with 125 subjects, variables with skewed distribution assessed using the Kolmogorov-Smirnov test of normality were log-transformed before the analysis, and they were analysed by parametric tests using a two-tailed independent $t$-test for comparison between groups, and two-tailed Pearson's correlation coefficient and linear regression analysis for relationships between variables. For the expression study, the Mann-Whitney U-test and Spearman's correlation were used. The validity of the regression model and its assumptions were assessed using the plot of residuals versus predicted. Multivariable linear regression analysis with the classical method was performed to analyse the association between RBP4 systemic concentrations and waist circumference, adjusting for possible confounding factors. Several models were carried out, including age, gender, insulin sensitivity (HOMA-IRI or fasting insulin) and lipid profile (HDL-c and TGL), and we chose the model with the best goodness of fit. In the same manner, multiple regression analysis was performed to analyse the association between RBP4 and adiponectin mRNA expressions, adjusting for age, gender and waist circumference (or BMI). The level of significance chosen was $P<0.05$.

\section{Results}

\section{Relationship between RBP4 and metabolic and anthropometric parameters}

As expected, the metabolic variables and parameters of IR analysed were significantly different between lean and obese patients (Table 1). However, while we did not find differences in RBP4 serum levels between lean and obese patients, serum adiponectin levels were significantly lower and CRP levels were significantly higher in the obese patients (Table 1).

In all subjects, there was a tendency for circulating RBP4 levels to be positively correlated with waist circumference $(r=0.24, P=0.06)$ and fasting insulin $(r=0.23, P=0.06)$, while there was no significant relationship between circulating RBP4 levels and BMI $(r=0.04, P=0.69)$, fasting glucose $(r=0.13$, $P=0.26$ ), blood pressure (SBP: $r=0.08, P=0.67$; DBP: $r=0.10, P=0.50)$ or the IR measured by either the HOMA-IRI $(r=0.13, P=0.32)$ or QUICKI indices $(r=-0.06, P=0.66)$. In addition, RBP4 was not correlated with the lipid profile parameters: total cholesterol $(r=0.33, P=0.60)$; triglycerides $(r=0.11$, $P=0.42)$; HDL-c $(r=0.13, P=0.30)$; and LDL-c $(r=0.21, P=0.14)$.

When the 38 subjects with the lowest and highest RBP4 serum levels were selected $(10.9 \pm 0.45$ vs 40.6 $\pm 0.7 \mu \mathrm{g} / \mathrm{ml} ; P<0.0001$ ), we found no difference in either the HOMA index of IR $(1.0 \pm 0.7$ vs $1.1 \pm 0.8$, $P=0.75)$ or the QUICKI index $(0.39 \pm 0.05$ vs 0.38 $\pm 0.04 ; P=0.93$ ) between each group.

In the multiple regression analysis, in a model including waist circumference and, as confounding factors, age, gender and HOMA-IRI, we found that waist circumference may independently explain the RBP4 systemic levels $\left(\beta=0.29, \quad P=0.08 ; R^{2}=0.08\right)$, although the circulating RBP4 levels were not significantly correlated with any parameter.

Likewise, we analysed the association between s.c.-AT RBP4 mRNA expression and the same parameters. The metabolic characteristics of the subpopulation from which s.c.-AT tissue samples were obtained (Table 2) were similar to those of the whole population (Table 1). We found that RBP4 mRNA expression was not correlated with the parameters described above $(P>0.09$ for all) with the exception of waist circumference, which was inversely correlated with RBP4 mRNA levels $(r=-0.33, P=0.03)$. Due to this significant relationship, we performed the correlation and the multiple regression analysis in lean and obese subjects separately. This association of mRNA RBP4 expression levels with waist circumference only remained in the obese group $(r=-0.56, P=0.01)$, even after a multivariable regression analysis in a model with age, gender and BMI as confounding factors $\left(\beta=-0.86, P=0.01 ; R^{2}=0.37\right)$. 


\section{Circulating RBP4, adiponectin and CRP and their expression in s.c. $A T$}

When the mRNA expression of RBP4, adiponectin and CRP was analysed in s.c.-AT from lean and obese subjects, we observed a significant downregulation of RBP4 and adiponectin (0.5-fold) and a significant increase in CRP expression (2.7-fold) in the obese population (Fig. 1A).

A comparison of the relative levels of the different molecules in the AT (Fig. 1A) showed a similar level of RBP4 and adiponectin expression $\left(1.3 \times 10^{\circ}\right.$ and 1.6 $\times 10^{0}$ respectively), whereas CRP expression $\left(8 \times 10^{-5}\right)$ was weak in comparison to both RBP4 and adiponectin.

Serum adiponectin levels were lower in the obese patients, whereas there was no difference in RBP4 protein levels between lean and obese subjects. Furthermore, the circulating CRP protein level was elevated in the obese patients (Fig. 1B).

In addition, the expression of RBP4 adiponectin or CRP levels in the s.c.-AT was not correlated with their circulating levels: $r=0.13, P=0.45$ for RBP $4 ; r=0.27$, $P=0.45$ for adiponectin; and $r=0.083, P=0.71$ for CRP.
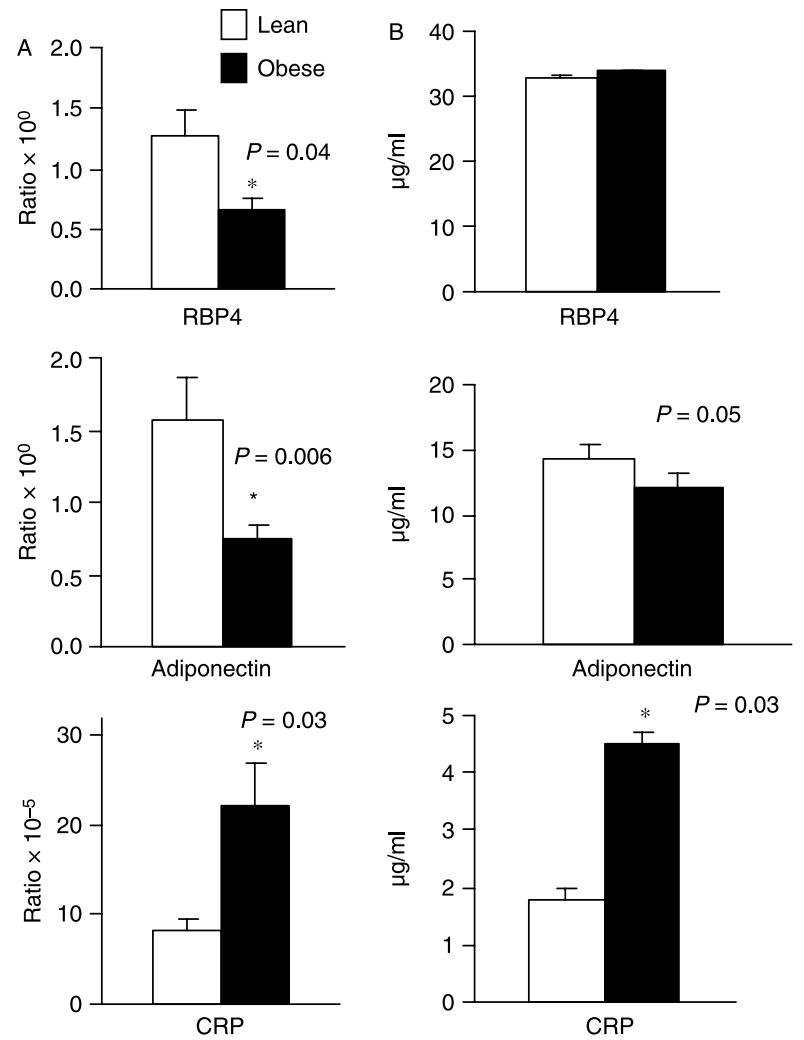

Figure 1 Subcutaneous adipose tissue mRNA expression and circulating levels of RBP4, adiponectin and CRP. RBP4, adiponectin and CRP mRNA expressions in subcutaneous adipose tissue (A) and protein circulating levels (B) of lean compared with obese subjects. Values are means \pm S.E.M. Ratio expresses mRNA gene/mRNA $\beta$-actin gene. Differences between groups were analysed using Mann-Whitney $U$-test. ${ }^{*}$ Denotes $P<0.05$.
Men and women expressed similar amounts of RBP4 mRNA in AT $\left(\right.$ ratio $=0.88 \times 10^{\circ} \pm 0.80 \times 10^{\circ}$ vs 1.0 $\left.\times 10^{\circ} \pm 0.78 \times 10^{\circ} ; P=0.72\right)$ and had similar circulating levels $(30.4 \pm 0.8$ vs $30.3 \pm 1.4 \mu \mathrm{g} / \mathrm{ml} ; P=0.77)$.

\section{RBP4, adiponectin and CRP expressions in cell fractions of $A T$}

RBP4 mRNA expression was analysed in the s.c.-AT fractions and was $\sim 500$-fold higher in the isolated mature adipocytes than in the non-fat cells of the SVF $(P=0.008$; Table 4). This pattern of RBP4 expression was similar to that of adiponectin, which was also preferentially expressed in the adipocyte fraction (Table 4). CRP expression was weak in both fractions (Table 4).

\section{Relationships between RBP4, adiponectin and CRP}

The circulating levels of RBP4 were not correlated with adiponectin or CRP levels ( $P>0.32$ both). The circulating levels of adiponectin were negatively correlated with the CRP levels in the whole population $(r=-0.41$, $P=0.009)$ and in obese patients $(r=-0.50, P=0.005)$.

Interestingly, RBP4 expression in the s.c.-AT was positively correlated with adiponectin expression in the whole population $(r=0.28, P<0.0001$; Fig. 2). This association was evident in the analysis of non-obese and obese subjects separately, yet it was only significant in the obese group $(r=0.35, P=0.11$ in lean; and $r=0.46, P=0.04$ in obese).

To ascertain how important the influence of adiponectin expression was on RBP4 mRNA expression, we used a multiple regression analysis model with the possible confounding factors of gender, age and waist circumference. The relationship between the expression of these two adipokines remained significant even after these adjustments, $\left(\beta=0.59, P<0.0001 ; R^{2}=0.40\right)$.

\section{Discussion}

Our analysis between the circulating RBP4 protein levels and parameters of obesity revealed a trend for RBP4 to be positively correlated with waist circumference even after adjusting for the effects of age, gender and HOMA-IRI. On the other hand, RBP4 was not associated with other parameters of adiposity, IR indices, blood pressure, glucose or lipid metabolism. The association of RBP4 with waist circumference suggests that this adipokine could be related to abdominal AT mass (subcutaneous and visceral AT), which has been strongly associated with metabolic disorders, including IR (20). 
Table 4 Relative expression of retinol-binding protein-4, adiponectin and C-reactive protein in isolated adipocytes and in the stromal vascular fraction of human subcutaneous adipose tissue.

\begin{tabular}{lccc}
\hline Gene & Adipocyte & SVF & P value \\
\hline RBP4 & $2.5 \times 10^{-1} \pm 6.2 \times 10^{-2}$ & $5.6 \times 10^{-4} \pm 2.6 \times 10^{-4}$ & $0.008^{*}$ \\
Adiponectin & $5.6 \times 10^{-1} \pm 1.0 \times 10^{-1}$ & $3.6 \times 10^{-6} \pm 1.8 \times 10^{-6}$ & $0.005^{*}$ \\
CRP & $4.0 \times 10^{-6} \pm 3.7 \times 10^{-8}$ & $2.6 \times 10^{-5} \pm 1.1 \times 10^{-5}$ & 0.2 \\
\hline
\end{tabular}

Subcutaneous adipose tissue biopsies were obtained from eight subjects and the two fractions were separated by collagenase digest. Expression by real-time PCR was expressed as ratio: mRNA of gene/mRNA $\beta$-actin gene and the results were the means \pm S.D. of values. *Indicates statistically significant difference $(P<0.05)$ using Mann-Whitney $U$-test.

The lack of relationship between circulating RBP4 levels and indices of IR was reported by us in a previous study (11), and is in agreement with several scientific reports $(12-14,21,22)$, but not with others $(7-10)$. The reason for such discrepancies among similar human studies remains unclear, although it has been suggested they may reflect methodological differences in the determination of RBP4 or IR parameters. In a recent article by Graham et al. (23) the nephelometric assay of RBP4, which we have used in this study, had a good correlation with RBP4 quantitative western blotting, which is the most reliable method for determining RBP4 protein levels in blood (23). Furthermore, the inclusion in the study population of subjects with diabetes (9) or morbid obesity (10), the differences in ethnicity (8) or the different age of the obese population (7), could affect the regulation of RBP4 and possibly contribute to such discrepancies. In our case, RBP4 was not related to IR in the same population in which, as expected $(18,19)$, an association of adiponectin with IR and the lipid profile was evident (data not shown).

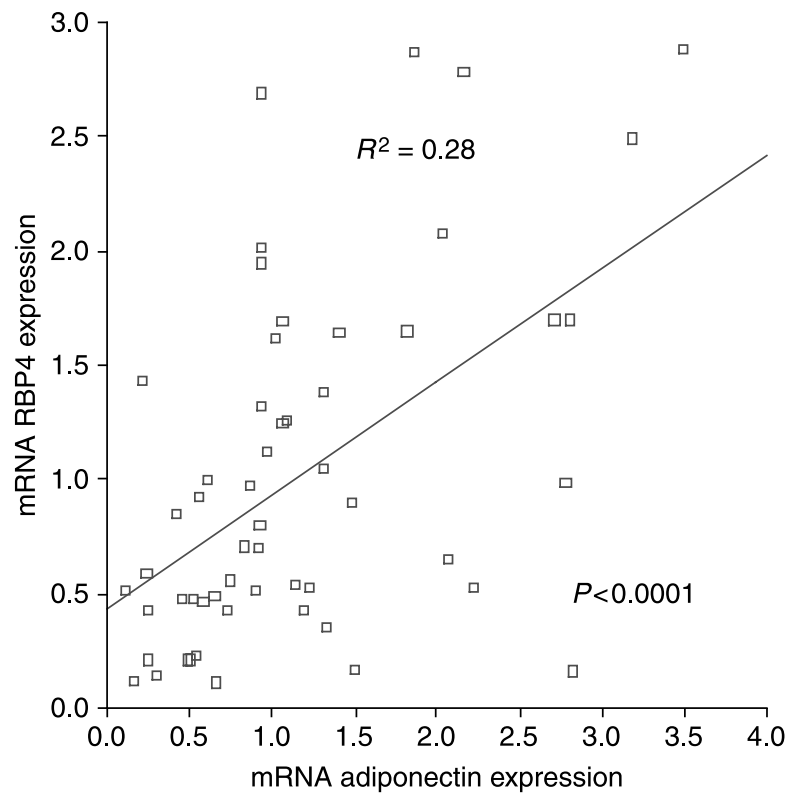

Figure 2 Relationship between RBP4 and adiponectin expression levels in subcutaneous adipose tissue in whole population. Values of $R^{2}$ and $P$ are from non-adjusted data.
Likewise, the statistical analysis of RBP4 mRNA expression in s.c.-AT showed that RBP4 did not associate with BMI, IR indices, blood pressure, glucose and lipid metabolism. However, we did find a significant negative correlation of RBP4 with waist circumference in this tissue, which was maintained even after adjusting for the effects of age, gender and BMI only in obese subjects. This finding is consistent with the downregulation of RBP4 mRNA expression in the obese population and points to other tissues as principal sources of serum RBP4, including visceral AT, muscle and liver (see below).

We show that, in human s.c.-AT, RBP4 mRNA expression levels are comparable to the mRNA levels of adiponectin, one of the most abundant adipokines (24). Interestingly, in cultures of human s.c.-AT explants, the rate of RBP4 protein observed was comparable with that of adiponectin (12). In addition, we found that both RBP4 and adiponectin were predominantly expressed in the mature adipocyte fraction of s.c.-AT, in agreement with other scientific reports $(12-14)$.

The mRNA expression of RBP4 and adiponectin diminished $\sim 50 \%$ in obese patients. However, downregulation of RBP4 and adiponectin in the s.c.-AT was not followed by a downregulation of the systemic RBP4 levels. This discrepancy between adiponectin and RBP4 could be due to the different tissues that express and secrete these two adipokines. Adiponectin is only expressed in AT, in classic and/or ectopic fat deposits (25), and it is established as a hormone released by the AT into the circulation. By contrast, RBP4 is expressed in the AT and other tissues such as liver, skeletal muscle and kidney (26). The contribution of AT and these other tissues to the systemic levels of RBP4 is not known in humans. It has been suggested that hepatocytes contribute to a large proportion of systemic RBP4 protein concentration (27), as it happens in rodents (28). Circulating RBP4 has also been related to the amount of fat accumulation in non-ATs such as skeletal muscle and the liver (29). Our observation of a decrease in RBP4 expression in the s.c.-AT while RBP4 circulating levels remained similar was also observed by Janke et al., in obese women compared with lean (14). In both studies, the subjects were non-diabetic and non-morbidly obese; it is possible that the inclusion of morbidly obese subjects could differentially affect the expression of RBP4 in s.c.-AT (10). 
RBP4 and adiponectin mRNA expressions were positively correlated and, interestingly, this correlation was also observed in the skeletal muscle of non-diabetic subjects by Ribel-Madsen et al. (30). The mechanisms that underlie the association between these two adipokines in s.c.-AT may be related to the reported autocrine action of adiponectin on primary adipocytes described previously (31).

On the other hand, we did not observe any relationship between RBP4 and CRP. Circulating CRP was inversely correlated with adiponectin levels in obese patients, as reported previously $(17,32)$. The failure to identify an association between circulating levels of RBP4 and CRP suggests that RBP4 is not directly associated with obesity-related low-grade inflammation.

One limitation of our expression study is that we only assessed adipokine expression in s.c.-AT, and thus we cannot translate these relationships to visceral AT where changes in systemic RBP4 levels have recently been associated with adipokine expression (33). Indeed, in this tissue single nucleotide polymorphisms of RBP4 have also been related to changes in RBP4 expression (34).

In summary, in this study, we have simultaneously examined RBP4, adiponectin and CRP expressions in the s.c.-AT, and we have compared their circulating levels in obese patients with those in lean subjects. Although the association of serum RBP4 with waist circumference may suggest a relationship with IR and other metabolic disorders, RBP4 circulating levels or mRNA expression were not significantly correlated with obesity-related parameters in our population. RBP4 was expressed at levels comparable to those of adiponectin, which is the most highly expressed adipokine in AT. Our results suggest that the production of RBP4 by other tissues such as liver, rather than s.c.-AT, may be involved in the fluctuations of its circulating levels.

\section{Declaration of interest}

The authors declare that no financial or other potential conflict of interests exists in relationship to this study.

\section{Funding}

This work was supported by research grant from the Spanish Ministerio de Educación y Ciencia (SAF2005-00413 and SAF200802278, both to C R) and by the 'Fundación Biociencia'.

\section{References}

1 Nedergaard J, Bengstsson T \& Cannon B. Unexpected evidence for active brown adipose tissue in adult humans. American Journal of Physiology. Endocrinology and Metabolism 2007293 444-452.

2 Lago F, Dieguez C, Gomez-Reino J \& Gualillo O. The emerging role of adipokines as a mediators of inflammation and immune resposes. Cytokine and Growth Factor Reviews 200718 313-325.
3 Knudson JD, Dick GM \& Tune JD. Adipokines and coronary vasomotor dysfunction. Experimental Biology and Medicine 2007 $232727-736$.

4 Haslam DW \& James WP. Obesity. Lancet 2005366 1197-1209.

5 Fantuzzi G. Adipose tissue, adipokines, and inflammation. Journal of Allergy and Clinical Immunology 2005115 911-919.

6 Yang Q, Graham TE, Mody N, Preitner F, Peroni OD, Zabolotny JM, Kotani K, Quadro L \& Kahn BB. Serum retinol binding protein 4 contributes to insulin resistance in obesity and type 2 diabetes. Nature $2005436356-362$.

7 Graham TE, Yang Q, Blüher M, Hammarstedt A, Ciaraldi TP, Henry RR, Wason CJ, Oberbach A, Jansson PA, Smith U \& Kahn BB. Retinol-binding protein 4 and insulin resistance in lean, obese, and diabetic subjects. New England Journal of Medicine 2006 $3542552-2563$.

8 Cho YM, Youn BS, Lee H, Lee N, Min SS, Kwak SH, Lee HK \& Park KS. Plasma retinol-binding protein 4 concentrations are elevated in human subjects with impaired glucose tolerance and type 2 diabetes. Diabetes Care 200629 2457-2461.

9 Craig RL, Chu SW \& Elbein SC. Retinol binding protein 4 as a candidate gene for type 2 diabetes and prediabeteic intermediate traits. Molecular Genetics and Metabolism 200690 338-344.

10 Kloting N, Graham TE, Berndt J, Kralisch S, Kovacs P, Wason CJ, Fasshauer M, Schön MR, Stumvoll M, Blüher M \& Kahn BB. Serum retinol-binding protein is more highly expressed in visceral than in subcutaneous adipose tissue and is a marker of intra-abdominal fat mass. Cell Metabolism 20076 79-87.

11 Broch M, Vendrell J, Ricart W, Richart C \& Fernández-Real JM. Circulating retinol-binding protein- 4 , insulin sensitivity, insulin secretion, and insulin disposition index in obese and nonobese subjects. Diabetes Care $2007301802-1806$.

12 Vitkota M, Klimcakova E, Kovacikova M, Valle C, Moro C, Polak J, Hanacek J, Capel F, Viguerie N, Richterova B, Bajzova M, Hejnova J, Stich V \& Langin D. Plasma levels and adipose tissue messenger ribonucleic acid expression of retinol-binding protein 4 are reduced during calorie restriction in obese subjects but are not related to diet-induced changes in insulin sensitivity. Journal of Clinical Endocrinology and Metabolism $2007 \mathbf{9 2}$ 2330-2335.

13 Yao-Borengasser A, Varma V, Boodles AM, Rasouli N, Phanavanh B, Lee MJ, Starks T, Kern LM, Spencer HJ III, Rashidi AA, McGehee RE Jr, Fried SK \& Kern PA. Retinol binding protein 4 expression in humans. Relationship to insulin resistance, inflammation, and resposte to pioglitazone. Journal of Clinical Endocrinology and Metabolism 200792 2590-2597.

14 Janke J, Engeli S, Boschmann M, Adams F, Böhnke J, Luft FC, Sharma AM \& Jordan J. Retinol-binding protein in human obesity. Diabetes $2006552805-2810$.

15 Herron DM. C-reactive protein and adiposity: obesity as a systemic inflammatory state. Surgery for Obesity and Related Diseases 20051 385-386.

16 Kern PA, Di Gregorio GB, Lu T, Rassouli N \& Ranganathan G. Adiponectin expression from human adipose tissue. Diabetes 2003 52 1779-1785.

17 Ouchi N, Kihara S, Funahashi T, Nakamura T, Nishida M, Kumada M, Okamoto Y, Ohashi K, Nagaretani H, Kishida K, Nishizawa H, Maeda N, Kobayashi H, Hiraoka H \& Matsuzawa Y. Reciprocal association of C-reactive protein with adiponectin in blood stream and adipose tissue. Circulation 2003107 671-674.

18 Yamamoto Y, Hirose H, Saito I, Nishikai K \& Saruta T. Adiponectin, an adipocyte-derived protein, predicts future insulin resistance: two-year follow-up study in Japanese population. Journal of Clinical Endocrinology and Metabolism 200489 87-90.

19 Arita Y, Kihara S, Ouchi N, Takahashi M, Maeda K, Miyagawa J, Hotta K, Shimomura I, Nakamura T, Miyaoka K, Kuriyama H, Nishida M, Yamashita S, Okubo K, Matsubara K, Muraguchi M, Ohmoto Y, Funahashi T \& Matsuzawa Y. Paradoxal decrease of an adipose-specific protein, adiponectin, in obesity. Biochemical and Biophysical Research Communications 1999257 79-83. 
20 Nilsson G, Hedberg P, Jonason T, Lönnberg I, Tenerz A, Forberg R \& Ohrvik J. Waist circumference alone predicts insulin resistance as good as the metabolic syndrome in elderly women. European Journal of Internal Medicine 200819 520-526.

21 Bajzová M, Kovaciková M, Vitková M, Klimcaková E, Polak J, Kovacová Z, Viguerie N, Vedral T, Mikulásêk L, Sramková P, Srp A, Hejnova J, Langin D \& Stich V. Retinol-binding protein 4 expression in visceral and subcutaneous fat in human obesity. Physiological Research 200857 927-934.

22 Lewis JG, Shand BI, Frampton CM, Elder PA \& Scott RS. Plasma retinol binding protein is not a marker of insulin resistance in overweight subjects: a three year longitudinal study. Clinical Biochemistry 200841 1034-1038.

23 Graham TE, Wason CJ, Blüher M \& Kahn BB. Shortcomings in methodology complicate measurements of serum retinol binding protein (RBP4) in insulin-resistant human subjects. Diabetologia 200750 814-823.

24 Fain JN, Madan AK, Hiler MLL, Cheema P \& Bahouth SW. Comparison of the release of adipokines by adipose tissue, adipose tissue matrix, and adipocytes from visceral and subcutaneous abdominal adipose tissues of obese humans. Endocrinology 2004 $1452273-2282$.

25 Perseghin G, Lattuada G, De Cobelli F, Esposito A, Belloni E, Canu T, Ragogna F, Scifo P, Del Maschio A \& Luzi L. Serum retinolbinding protein-4, leptin and adiponectin concentrations are related to ectopic fat accumulation. Journal of Clinical Endocrinology and Metabolism 200792 4883-4888.

26 Soprano DR, Soprano KJ \& Goodman DS. Retinol-binding protein messenger RNA levels in the liver and in extrahepatic tissues of the rat. Journal of Lipid Research 198627 166-171.

27 Blaner WS. Retinol-binding protein: the serum transport protein for vitamin A. Endocrine Reviews 198910 308-316.
28 Tsutsumi C, Okuno M, Tannous L, Piantedosi R, Allan M, Witt SGD \& Blaner WS. Retinoids and retinoid-binding protein expression in rat adipocytes. Journal of Biological Chemistry 1992267 1805-1810.

29 Stefan N, Hennige AM, Staiger H, Machann J, Schick F, Schleicher E, Fritsche A \& Haring H-U. High circulating retinolbinding protein 4 is associated with elevated liver fat but not with total, subcutaneous, visceral, or intramyocellular fat in humans. Diabetes Care 200730 1173-1178.

30 Ribel-Madsen R, Friedrichsen M, Vaag A \& Poulsen P. Retinolbinding protein 4 in twins-regulation mechanisms and impact of circulating and tissue expression levels on insulin secretion and action. Diabetes 200958 54-60.

31 Dietze-Schroeder D, Sell H, Uhlig M, Koenen M \& Eckel J. Autocrine action of adiponectin on humans fat cells prevents the release of insulin resistance-inducing factors. Diabetes $2005 \mathbf{5 4} 2003-2011$.

32 Matsubara M, Namioka K \& Katayose S. Decreased plasma adiponectin concentrations in women with low-grade C-reactive protein elevation. European Journal of Endocrinology 2003148 657-662.

33 Lee JW, Lee HR, Shim JY, Im JA \& Lee DC. Addominal visceral fat reduction is associated with favorable changes of serum retinol binding protein-4 in nondiabetic subjects. Endocrine Journal 2008 55 811-818.

34 Kovacs P, Geyer M, Berndt J, Klöting N, Graham TE, Böttcher Y, Enigk B, Tönjes A, Schleinitz D, Schön MR, Kahn BB, Blüher M \& Stumvoll M. Effects of genetic variation in the human retinol binding protein-4 (RBP4) on insulin resistance and fat depotspecific mRNA expression. Diabetes 200756 3095-3100.

Received 27 March 2009

Accepted 10 April 2009 